\title{
Microglial microvesicle secretion and intercellular signaling
}

\author{
Elena Turola ${ }^{1,2}$, Roberto Furlan ${ }^{3}$, Fabio Bianco ${ }^{1,2}$, Michela Matteoli ${ }^{1,2,4}$ and Claudia Verderio ${ }^{1,2 *}$ \\ ${ }^{1}$ CNR Institute of Neuroscience, Milano, Italy \\ ${ }^{2}$ Department of Medical Pharmacology, Università di Milano, Milano, Italy \\ ${ }^{3}$ INSPE, Division of Neuroscience, Fondazione San Raffaele del Monte Tabor, Milano, Italy \\ ${ }^{4}$ Istituto Clinico IRCCS Humanitas, Milan, Italy
}

Edited by:

Mauro Maccarrone, University of Teramo, Italy

Reviewed by:

Giuseppe Astarita, University

California Irvine, USA

Maria Marino, University Rma Tre, Italy

\section{*Correspondence}

Claudia Verderio, CNR Institute of

Neuroscience, Via Vanvitelli 32, 20129

Milano, Italy.

e-mail:c.verderio@in.cnr.it
Microvesicles (MVs) are released from almost all cell brain types into the microenvironment and are emerging as a novel way of cell-to-cell communication. This review focuses on MVs discharged by microglial cells, the brain resident myeloid cells, which comprise 10-12\% of brain population. We summarize first evidence indicating that MV shedding is a process activated by the ATP receptor $\mathrm{P}_{2} \mathrm{X}_{7}$ and that shed MVs represent a secretory pathway for the inflammatory cytokine IL- $\beta$. We then discuss subsequent findings which clarify how IL-1 $\beta$ can be locally processed and released from MVs into the extracellular environment. In addition, we describe the current understanding about the mechanism of P2X $\mathrm{X}_{7}$-dependent MV formation and membrane abscission, which, by involving sphingomyelinase activity and ceramide formation, may share similarities with exosome biogenesis. Finally we report our recent results which show that microglia-derived MVs can stimulate neuronal activity and participate to the propagation of inflammatory signals, and suggest new areas for future investigation.

Keywords: microvesicles, microglial cells, IL-beta, neuronal activity, brain inflammation

\section{SUBCELLULAR ORIGIN AND COMPOSITION OF MVs SHED FROM THE CELL SURFACE}

Microvesicles (MVs), also referred to as shed vesicles or ectosomes (Sadallah et al., 2011), are small $(0.1-1 \mu \mathrm{m})$ vesicles which bud directly from the plasma membrane and are released into the extracellular environment upon cell activation. Shedding of MVs typically involves a budding process, in which surface blebs selectively accumulate cellular constituents that are packaged into MVs. MVs contain a variety of cell surface receptors, intracellular signaling proteins and genetic materials derived from the cell of origin. In terms of composition, MVs originating from distinct cell types are molecularly different from each other, reflecting the differential expression of proteins of various donor cells. Composition and biological activity of MVs also vary depending on the state (e.g., resting, stimulated) of donor cells and on the agent employed for stimulation (Bernimoulin et al., 2009). The mechanisms involved in MV budding and discharge are beginning to emerge and suggest the involvement of ESCRT and/or ARF6 (Cocucci et al., 2009; Muralidharan-Chari et al., 2009; Gan and Gould, 2011).

Besides MVs, most cells secrete into the environment a markedly distinct type of small extracellular vesicles by an alternative two-step process. This mechanism includes the bud of intraluminal vesicles at endosomes during multivesicular bodies (MVBs) maturation and subsequent vesicle secretion upon fusion of MVBs with the plasma membrane (Cocucci et al., 2009;

Abbreviations: A-SMase, acid sphingomyelinase; CNS, central nervous system; ESCRT, endosomal sorting complex required for transport; MVs, microvesicles; MVBs, multi vesicular bodies; PS, phosphatidylserine; SM, sphingomyelin.
Simons and Raposo, 2009). Small (40-80 nm) extracellular vesicles released by this process are called exosomes and represent a more homogeneous type of vesicles, enriched in specific components (tetraspanning proteins, CD63 and CD9, and alix).

\section{BIOLOGICAL ACTIVITY AND MECHANISM OF MV INTERACTION WITH TARGET CELLS}

Until a decade ago, MVs were considered as in vitro artifact, or alternatively regarded as a way of eliminating unwanted material from cells. MVs were also often confused with apoptotic bodies generating during cell death or with exosomes, discharged upon fusion of MVBs with the plasma membrane. Several reasons may explain why for many years MVs have been largely overlooked. First, discriminating between different types of extracellular vesicles is difficult and requires a combination of electron microscopy and biochemical techniques. In addition, while the presence of markers of endosomal origin (alix, Tg110, CD63, and CD9) is an accepted criterion to identify exosomes, no universal markers have been identified yet for MVs discharged outside the cells from the cell surface, which are highly heterogeneous in composition. Also, studies of MVs have been constrained by the limitations of current methodology employed for their isolation and quantification. MVs are usually isolated from culture medium or body fluids by differential centrifugation or affinity capture. However, immunosorbent or bead capture assays do not allow isolating all the vesicles present in the samples and differences in centrifuge speeds used to eliminate whole cells may discard materials which in different laboratories are measured as MVs (Horstman et al., 2007). Furthermore the most widely used 
methods to quantify MVs, i.e., flow cytometry and dynamic light scattering, are biased toward the detection or larger MVs (Dragovic et al., 2011). Although interesting advances in MV quantification and isolation have been recently achieved with introduction of new methodology such as a nanoparticle tracking or micro- and nano fluidics (Chen et al., 2010), these new technologies for sizing and quantifying MVs still need to be standardized in order to provide reliable and reproducible methods. Despite these technical limitations, now-a-days MVs attract great interest as their shedding is recognized as a widespread mode of intercellular communication in different body compartments. Indeed shed MVs, similarly to exosomes, may serve as information packets to guide the phenotype of surrounding cells by transferring lipids, proteins, and genetic material from donor to target cells (Thery et al., 2009). Furthermore shed MVs, being enriched in various bioactive molecules, play pleiotropic roles in many physiological processes, including development (Liegeois et al., 2006; Kolotuev et al., 2009), coagulation, and immune reaction (Thery et al., 2009), as well as in diseases, such as cancer progression (Yu et al., 2006, 2009; Keller et al., 2009; Gan and Gould, 2011), viral infection (Dukers et al., 2000; Gould et al., 2003; Fang et al., 2007; Logozzi et al., 2009; Nazarenko et al., 2010), and amyloidopathies (Fevrier et al., 2004; Leblanc et al., 2006; Alais et al., 2008). Released MVs may remain in the extracellular space in close proximity to the place of origin or move by diffusion and enter biological fluids, such as blood, urine, and synovial fluid, where they are emerging as clinically valuable markers of disease states (Doeuvre et al., 2009). MVs have the same topology as the cell of origin but loose membrane asymmetry and are characterized by the presence of the phospholipid phosphatidylserine (PS) externalized at their surface (Zwaal and Schroit, 1997; Sims and Wiedmer, 2001). PS exposed on shed MVs represents a determinant for recognition on recipient cells, through binding to the corresponding cellular PS receptors (AlNedawi et al., 2009). The interaction of MVs with recipient cells can be followed by fusion or endocytosis. Alternatively, MVs can undergo rupture and release their luminal active components, thus modulating, by protein secretion, the activity of target cells.

\section{BLEBBING AND MV FORMATION INDUCED BY P2X RECEPTOR ACTIVATION}

A specialized type of MV release exists for cells that express the ATP receptor $\mathrm{P}_{2} \mathrm{X}_{7}$, and which shed MVs from the cell surface when this receptor is activated by ATP. $\mathrm{P}_{2} \mathrm{X}_{7}$ receptor is an ATPgated ion channel highly expressed in immune cells, particularly macrophages (Steinberg et al., 1987) mast cells (Cockcroft and Gomperts, 1979), and microglia (Visentin and Levi, 1997) where it controls the release of inflammatory cytokines, such as IL- $1 \beta$ and IL-18 (Ferrari et al., 2006). Activation of $\mathrm{P}_{2} \mathrm{X}_{7}$ receptor induces efficient assembly of inflammosome, the protein complex which activates the IL- $1 \beta$ processing enzyme caspase- 1 . This process is followed by rapid cytokine secretion (Qu et al., 2007). P2X 7 receptor differs from other members of the P2X family in its relatively low affinity for ATP and the presence of a long cytoplasmic Cterminus that contains several protein-protein interaction motifs. Depending on the ATP concentration and time of exposure, $\mathrm{P}_{2} \mathrm{X}_{7}$ receptor functions as either an ion channel or a non-selective pore, the latter generally leading to cytotoxicity and apoptotic cell death. Many studies have shown that dramatic morphological changes occur in cells endogenously or heterologously expressing $\mathrm{P}_{2} \mathrm{X}_{7}$ receptors during and subsequent to receptor activation (Hogquist et al., 1991; Ferrari et al., 1997). These changes consist in rapid formation of cell membrane blebs and are associated to cell death upon sustained $\mathrm{P}_{2} \mathrm{X}_{7}$ receptor activation. Membrane blebbing results from several intracellular signaling events, which are induced by occupancy of the receptor, such as the activation of protein kinases and other effector enzymes (Duan and Neary, 2006). In particular, several lines of evidence indicate that $\mathrm{P} 2 \mathrm{X}_{7}-$ induced blebbing is dependent upon P38 and requires ROCK activation, which causes local disassembly of the cytoskeletal elements, associated to the $\mathrm{P}_{2} \mathrm{X}_{7}$ C-terminus (Budagian et al., 2003; Morelli et al., 2003; Verhoef et al., 2003). Notably, surface blebbing is preceded by loss of plasma membrane asymmetry and exposure of phosphatidylserine (PS) at the outer leaflet of the plasma membrane, a process controlled by specific enzymes, named flippase, floppase, and lipid scramblase, which control PS segregation in the inner leaflet of the plasma membrane (Hugel et al., 2005). Externalized PS is a commonly accepted marker for cell apoptosis. However, a pioneer study by Surprenant and colleagues (MacKenzie et al., 2001) dissociated the $\mathrm{P}_{2} \mathrm{X}_{7}$-induced bleb formation from cell apoptosis, by showing in monocytes that $\mathrm{P}_{2} \mathrm{X}_{7}$-induced $\mathrm{PS}$ externalization and bleb formation occur within the first few minutes of receptor activation and is reversible after brief stimulation. MacKenzye and colleagues also showed that, during blebbing, MVs with externalized PS can be formed and released into the extracellular space as a result of bleb detachment from the cell surface. Notably the pro-inflammatory cytokine IL- $1 \beta$ is packaged into plasma membrane blebs, which are subsequently shed, as MVs, into the extracellular space from reactive monocytes (Figure 1A). Almost ten years ago these results provided the first evidence that $\mathrm{P}_{2} \mathrm{X}_{7}$-induced $\mathrm{MV}$ shedding acts as a secretory pathway for rapid release of IL-1 $\beta$ and may represent a general mechanism for secretion of leaderless secretory proteins from $\mathrm{P}_{2} \mathrm{X}_{7}$-expressing myeloid cells.

\section{EMERGING ROLE OF MVs DERIVED FROM BRAIN CELLS: P2X-DEPENDENT MV SHEDDING AND IL-1 $\beta$ RELEASE IN MICROGLIA}

In the recent years, a series of studies has indicated relevant physiological and pathological functions for extracellular vesicles within the brain. These functions include fundamental processes occurring in brain, such as axonal growth and regeneration, axon-glia communication, inter-neuronal transfer of information across synapses, modulation of neuro-immune interactions, as well as disease-associated events, including tumor progression, and spreading of pathogenic agents or misfolded proteins. The majority of these studies focused, however, on exosomes rather than MVs shed from the cell surface of brain cells (Table 1). Indeed only one report indicates the existence of MVs of neuronal origin (Schiera et al., 2007) and there is no evidence for shedding of MVs from oligodendrocytes. Nevertheless, a mixed population of MVs and exosomes has been detected in vivo in the cerebrospinal fluid isolated from sheep (Vella et al., 2008), and our recent evidence indicate that a fraction of large MVs (mean size $=420 \mathrm{~nm}$ ) pelleted from rat CSF by differential centrifugation 
displays neuronal or oligodendroglial markers (Verderio et al., 2012), suggesting that even neurons, and oligodendrocytes produce MVs in vivo. Larger interest has been raised so far by MVs shed from the cell surface of microglia, the immune cells of the nervous system, which play key role in inflammatory and degenerative brain pathologies. Microglial cells are brain resident myeloid cells, which migrate into the CNS during early embryogenesis and comprise $\sim 10-12 \%$ of total brain population (Ransohoff and Cardona, 2010). Although they are traditionally distinguished from infiltrating peripheral macrophages, which can migrate to the brain from blood upon CNS damage or inflammation and do not differentiate into microglia, in the injured CNS, activated microglia and infiltrating macrophages cannot be distinguished by their morphology or by specific antigenic markers.

As immune cells, the primary function of microglia is to maintain brain tissue homeostasis, to provide the first line of defense
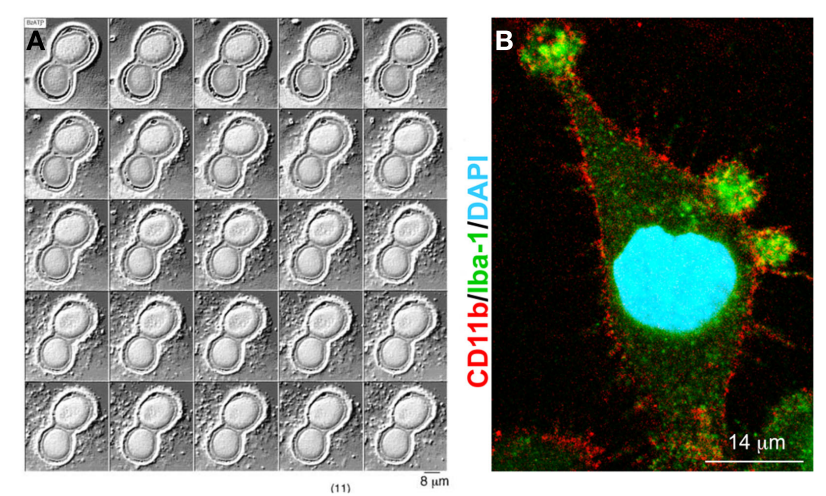

FIGURE 1 | $\mathrm{P}^{2} \mathrm{X}_{7}$ receptor-induced MV shedding from monocytes and microglial cells. (A) Fluorescent images of two THP-1 monocytes labeled with NBD membrane, NBD-labeled particle shedding, and membrane bleb during exposure to BzATP. From MacKenzie et al. (2001). (B) Fluorescent image of a cultured microglial cell exposed for $48 \mathrm{~h}$ to a cocktail of inflammatory cytokines, stained for lba-1 (green), CD11b (red), and DAPI (blue). Note the presence of many blebs at the cell surface double positive for Iba-1 and Cd11b. From Verderio et al. (2012). during infection or brain injury and to promote tissue repair. In normal brain "surveillant" microglia display a ramified morphology, characterized by long and thin processes, which communicate with surrounding neurons and other glial cells and continuously scan the microenvironment to exert a guard function for incoming pathogens and brain alterations. In response to many types of alarm signals (cytokines, material from apoptotic cells, and exogenous viral factors) "surveillant" microglia undergo several levels of activation and migrate to the site of infection or injury to eliminate pathogens or to phagocyte dead cells and protein aggregates. Depending upon the nature and duration of environmental signals, microglia can undergo a "classical" pro-inflammatory activation, transforming into fully activated inflammatory effector cells (cytokines-secreting cells), or an "alternative" activation, generally associated with tuning of inflammatory response, protection from disease, and tissue repair. These two extremes along multiple states of microglia activation are commonly indicated as M1 (pro-inflammatory) and M2 (pro-regenerative) phenotypes, in analogy to the distinction originally made between M1 and M2 macrophages (Mantovani and Locati, 2009; David and Kroner, 2011; Saijo and Glass, 2011). Experimentally, these states are commonly achieved by treating cells in vitro with polarizing agents, such as anti inflammatory cytokines (Saijo and Glass, 2011).

A few years ago we reported that a MV-mediated mechanism for IL-1 $\beta$ release occurs in microglial cells (Bianco et al., 2005), very similar to that first described in monocytes (MacKenzie et al., 2001). By video microscopy experiments, we showed that cultured microglia form membrane blebs (Figure 1B) and shed MVs from the cell surface upon $\mathrm{P}_{2} \mathrm{X}_{7}$ receptor activation. Isolation of MVs produced from reactive microglia, followed by IL- $1 \beta$ evaluation by ELISA or western blotting revealed that MVs produced by LPS-treated microglia store and subsequently release IL- $1 \beta$ into the environment in an ATP- and P2X $\mathrm{X}_{7}$-dependent manner. IL- $1 \beta$ efflux from shed MVs is enhanced by ATP stimulation and inhibited by pretreatment with the $\mathrm{P}_{2} \mathrm{X}_{7}$ receptor antagonist oxidized ATP, thus indicating a crucial involvement of the pore-forming $\mathrm{P}_{2} \mathrm{X}_{7}$ receptor in the release of the cytokine. Notably, we found that shedding of MVs from microglial cells is not only promoted

Table 1 | Microvesicles of different brain cell origin.

\begin{tabular}{|c|c|c|c|}
\hline Cell of origin & Exosomes & Ectosomes/shed MVs & Mixed population \\
\hline Astrocytes & $\begin{array}{l}\text { Taylor et al. (2007), Bianco et al. (2009), } \\
\text { Guescini et al. (2010), Sbai et al. (2010), } \\
\text { Wang et al. (2011) }\end{array}$ & Bianco et al. (2005) & $\begin{array}{l}\text { Proia et al. (2008), Ceruti et al. (2011), } \\
\text { Verderio et al., 2012; in vivo) }\end{array}$ \\
\hline Microglia & $\begin{array}{l}\text { Potolicchio et al. (2005), Bianco et al. } \\
\text { (2009), Tamboli et al. (2010) }\end{array}$ & $\begin{array}{l}\text { Bianco et al. (2005, 2009), Chahed } \\
\text { et al. (2010), Tamboli et al. (2010), } \\
\text { Antonucci et al. (2012), Verderio } \\
\text { et al. (2012) }\end{array}$ & Verderio et al., 2012; in vivo) \\
\hline Oligodendrocytes & $\begin{array}{l}\text { Kramer-Albers et al. (2007), Trajkovic et al. } \\
\text { (2008), Strauss et al. (2010), Fitzner et al. } \\
\text { (2011), Bakhti et al. (2011) }\end{array}$ & & $\begin{array}{l}\text { Scolding et al., 1989; in vivo), Verderio } \\
\text { et al., 2012; in vivo) }\end{array}$ \\
\hline Neurons & $\begin{array}{l}\text { Faure et al. (2006), Korkut et al. (2009), } \\
\text { Lachenal et al. (2011), Ghidoni et al. (2011), } \\
\text { Yuyama et al. (2012) }\end{array}$ & & $\begin{array}{l}\text { Schiera et al. (2007), Verderio et al., 2012; } \\
\text { (in vivo) }\end{array}$ \\
\hline
\end{tabular}


by $\mathrm{P}_{2} \mathrm{X}_{7}$ receptor activation through exogenous ATP, but also by ATP endogenously released from healthy astrocytes in astrocytemicroglia co-cultures. Although ATP is typically considered a danger signal, this observation represented a first indication that MVs can be released from microglia even in the absence of cellular damage.

\section{HOW DOES IL-1 $\beta$ GET THROUGH THE MEMBRANE OF MVs?}

The MV-mediated mechanism for IL- $1 \beta$ release originally proposed by Surprenant's laboratory left a question unsolved: how does mature IL- $1 \beta$ get through the membrane of MVs and reach the extracellular space? Later observations from our laboratory (Bianco et al., 2005) and from Di Virgilio's group (Ferrari et al., 2006; Pizzirani et al., 2007) provided a possible answer: MVs shed from microglia and dendritic cells, bear $\mathrm{P}_{2} \mathrm{X}_{7}$ receptors in their membranes and are loaded with caspase- 1 . This enzyme becomes activated upon $\mathrm{P}_{2} \mathrm{X}_{7}$ receptor stimulation and is responsible for intravesicular processing of the biological inactive precursor of IL-1 $\beta$ (pro-IL-1 $\beta$ ) into the active form of the cytokine. Recent evidence obtained in macrophages confirmed these findings by showing that extracellular vesicles, both exosomes and shed MVs, carry components of the inflammosome, in addition to the IL-1 $\beta$ converting enzyme (Qu et al., 2009; Sarkar et al., 2009).

Notably, activation of $\mathrm{P}_{2} \mathrm{X}_{7}$ receptors, followed by opening of large pores and MV lysis may represent the mechanism by which IL- $1 \beta$ gets through membrane of MVs. $\mathrm{P}_{2} \mathrm{X}_{7}$-dependent disruption of MVs was indeed reported to mediate the efflux of IL-1 $\beta$ from dendritic cells (Ferrari et al., 2006). However, differently from what described in dendritic cells, we found that IL- $1 \beta$ release from microglia is not the consequence of MV lysis. This was indicated by the observation that IL- $1 \beta$ release is not paralleled by GFP efflux from GFP-labeled MVs, produced by N9 microglial cells (Balcaitis et al., 2005), which stably express the fluorescent protein (Bianco et al., 2005). GFP is a 40-kDa cytosolic protein, that can be released extracellularly upon $\mathrm{MV}$ disruption but not through the $\mathrm{P}_{2} \mathrm{X}_{7}$ pore, which is permeable to molecules up to $1 \mathrm{kDa}$.

Although further studies are necessary to better define how IL$1 \beta$ gets through membrane of MVs, it can be hypothesized that, once microglia-derived MVs approach the plasma membrane of target cells, where the ATP concentration is higher than in the bulk solution, the $\mathrm{P} 2 \mathrm{X}_{7}$ receptor is activated, $\mathrm{IL}-1 \beta$ is processed by caspase- 1 , and released from MVs.

\section{BIOGENESIS OF MVS INDUCED BY P2X ${ }_{7}$ RECEPTOR ACTIVATION}

Microvesicles emanate from viable cells through the outward blebbing of their plasma membrane. Budding of MVs shares many features with budding of viral particles and intraluminal vesicle budding inside endosomes, during MVBs biogenesis. The latter process occurs through the invagination of small intraluminal vesicles of about $50 \mathrm{~nm}$ in diameter which then pinch off from the endosomal membrane and are released extracellularly as exosomes, upon fusion of MVBs with the plasma membrane. Exosome formation, as well as the egress of a few enveloped viruses, is generally dependent on the ESCRT (endosomal sorting complex required for transport) machinery, which regulates membrane scission. Recent studies indicated that fission of exosome membrane is catalyzed, in particular, by components of the ESCRT-III complex, called charged multivesicular body proteins (CHMPs; Hanson et al., 2009; Wollert et al., 2009; Wollert and Hurley, 2010) and by the AAA-ATPase vacuolar protein sortingassociated 4 (VPS4; Babst, 2005). Other pathways that promotes exosome biogenesis are emerging, which depend on lipids raft composition, the phospholipid LBPA (Matsuo et al., 2004), the sphingolipid ceramide, and activity of neutral sphingomyelinase (Trajkovic et al., 2008). However it is still unclear how these factors combine to promote exosome secretion (Gan and Gould, 2011). Trajkovic and coworker, for example, clearly showed that enrichment in ceramide is sufficient to trigger spontaneous vesiculation by an invagination mechanism which is independent of the ESCRT machinery, thus suggesting that distinct mechanisms may control the biogenesis of specific subsets of exosomes.

A few years ago we gained some insights into the molecular mechanism which mediates bleb formations and (exo)vesiculation upon activation of $\mathrm{P}_{2} \mathrm{X}_{7}$ receptor in glial cells, both microglia and astrocytes (Bianco et al., 2009). It was known that $\mathrm{P}_{2} \mathrm{X}_{7}$-dependent blebbing is preceded by alteration of the transbilayer lipid distribution and requires ROCK and P38 MAP kinase activation, similarly to apoptotic blebbing (Piccin et al., 2007; Al-Nedawi et al., 2009; Pap et al., 2009; Cocucci and Meldolesi, 2011). However an unsolved question was how signaling by $\mathrm{P}_{2} \mathrm{X}_{7}$ receptor leads to alterations of the biophysical properties of the plasma membrane, which together with actin-cytoskeleton re-organization are a prerequisite for membrane blebbing and vesiculation at the surface of healthy cells.

We found that biogenesis of MVs storing IL- $1 \beta$ is controlled by acid sphingomyelinase (A-SMase), the enzyme which hydrolyzes sphingomyelin $(\mathrm{SM})$ to the sphingolipid ceramide. Following $\mathrm{P}_{2} \mathrm{X}_{7}$ receptor activation, a src-protein tyrosine kinase interacts with the C-terminus of the receptor (Denlinger et al., 2001) and promptly phosphorylates P38 MAP kinase. P38 phosphorylation, in turn, induces translocation of A-SMase to the plasma membrane outer leaflet, where it generates ceramide, thereby inducing budding of MVs (Bianco et al., 2009; Figure 2). Although ASMase has been historically associated to lysosomes, our data are consistent with evidence indicating that the enzyme is activated rapidly upon stimulation of various receptors, and is recruited to the plasma membrane to mediate receptor-dependent signaling (Grassme et al., 2001; Gulbins and Kolesnick, 2003; Marchesini and Hannun, 2004; Perrotta et al., 2010). Formation of blebs is likely caused by redistribution of extracellularly synthesized ceramide within the bilayer and by local enrichment of the coneshape sphingolipid into the inner leaflet of the membrane. Indeed due to its spontaneous negative curvature, ceramide may induce membrane subdomains with curvature different from the adjacent planar membrane (Subra et al., 2007). In addition, hydrolysis of SM, which has a high affinity for cholesterol, may result in increased efflux of cholesterol. As this lipid is a major determinant of membrane fluidity and structural integrity of the plasma membrane (Simons and Ikonen, 1997) cholesterol efflux may cause an increase in membrane fluidity (Slotte et al., 1989; Neufeld et al., 1996) thus contributing to membrane destabilization and facilitating blebbing and MV shedding (Van Blitterswijk et al., 1982; Chang et al., 1993; Tepper et al., 2000). Bleb formation probably 


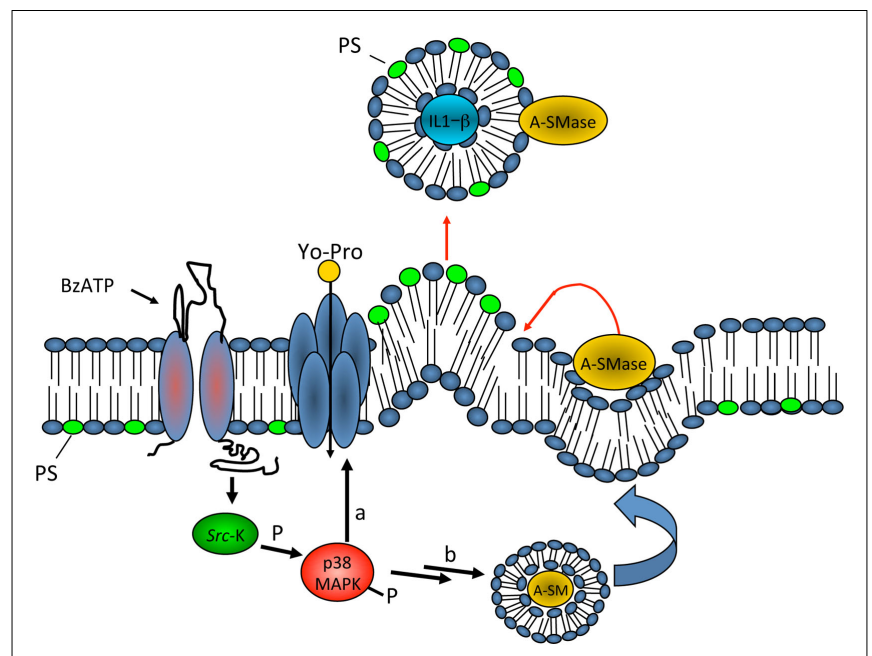

FIGURE 2 | Model for $\mathrm{P}_{2} \mathrm{X}_{7}$ receptor-induced signaling pathway involved in $\mathbf{M V}$ shedding. On stimulation with ATP or the selective agonist BzATP, P2X7 receptor activates P38 cascade through src-kinase-mediated phosphorylation. In turn, P38 triggers different pathways, among which PM pore formation (a), and mobilization of A-SMase from luminal lysosomal compartment to plasma membrane outer leaflet (b) where the enzyme alters membrane structure/fluidity leading to plasma membrane blebbing and shedding. Shed MVs carry IL-1 $\beta$, present A-SMase and high levels of PS on their membrane outer leaflet. From Bianco et al. (2009)

occurs from surface lipid rafts (Del Conde et al., 2005), where the $\mathrm{P}_{2} \mathrm{X}_{7}$ receptor localizes. In such domains, cytoskeleton/membrane proteins, directly interacting with the $\mathrm{P}_{2} \mathrm{X}_{7}$ receptor or $\mathrm{P} 2 \mathrm{X}_{7}$ receptor-dependent signaling components, can be recruited. We demonstrated the key role of A-SMase in MV formation using the pharmacological inhibitor imipramine, and genetic inactivation of the enzyme. Both approaches strongly abolished release of MVs and of IL-1 $\beta$ from reactive glial cells (Bianco et al., 2009).

Other pathways besides shed MVs have been proposed to mediate IL- $1 \beta$ release from myeloid cells, including exosomes and exocytosis of secretory lysosomes (Andrei et al., 1999; Qu et al., 2007). However, enrichment of IL-1 $\beta$ in larger MVs, derived from the plasma membrane, and complete blockade of MV shedding and IL- $1 \beta$ release from A-SMase KO cells indicates that MV shedding represents the major mechanism mediating secretion of the inflammatory cytokine from reactive microglial cells.

Our results are consistent with the involvement of neutral sphingomyelinase and ceramide formation in the budding of exosomes in oligodendrocytes (Trajkovic et al., 2008) and represent further evidence that $\mathrm{MV}$ budding may share features with exosome biogenesis. The role of acid-rather than neutralsphigomyelinase in MV formation suggests that different members of the SMase family may control the release of distinct types of extracellular vesicles from brain cells, independently of the ESCRT complex.

What remains to be clarified is whether acid SMase activity may play a general role in shedding of MVs that occurs independently of $\mathrm{P}_{2} \mathrm{X}_{7}$ activation, such as discharge of MVs from the plasma membrane of highly proliferating cells, which is involved in tumor growth and invasion. Similarly, it remains to be determined if sphingomyelinase activity and ceramide production may be also involved in nanotube formation, by promoting the protrusion of filopodia - like structures which then extend as tubes toward distant cells.

\section{WHY DO MICROGLIA USE MVs TO RELEASE IL-1 $\beta$ ?}

Which is the main advantage for a cell to release IL- $1 \beta$ through MVs rather than exporting the cytokine directly? Shed MVs, containing packages of IL- $1 \beta$, can deliver the cytokine at significant distance from the donor cell, in possible proximity to IL- $1 \beta$ receptors present on target cells, thus preventing dispersal and degradation and avoiding dilution of the cytokine in the extracellular environment. Furthermore, TNF $\alpha$ (Hide et al., 2000) and proteases, such as caspase-1 and cathepsin D (Qu et al., 2009; Sarkar et al., 2009), which are synthesized and released upon $\mathrm{P}_{2} \mathrm{X}_{7}$ receptor activation, could be released via MVs together with IL-1 $\beta$. Biogenesis of MVs may indeed serve as a mechanism of regulated assembly of multiple factors (Al-Nedawi et al., 2009) and reactive microglial cells may use MVs as complex "units" of information to mediate an integrated biological response. The presence of inflammatory cytokines and proteolytic agents might be important for the onset of detrimental effects of MVs toward degenerating cells, which are known to release large amounts of ATP, thereby promoting MV shedding. In this regard, monocytes-derived MVs, containing functional caspase-1, have been described to deliver a cell death message to vascular smooth muscle cells (Sarkar et al., 2009).

\section{ROLE OF MICROGLIA-DERIVED MVs IN BRAIN INFLAMMATION}

Notably, besides inflammatory mediators and proteases, MVs shed upon $\mathrm{P}_{2} \mathrm{X}_{7}$-activation from monocytes and dendritic cells contains MHCII proteins (Qu et al., 2009). This suggests that MVs produced from reactive myeloid cells may provide an efficient route for rapid dissemination and presentation of antigens, as part of an adaptive immune response. Indeed it has been recently shown that MVs shed by macrophages upon $\mathrm{P}_{2} \mathrm{X}_{7}$ receptor activation propagate an inflammatory signal among peripheral immune cells (Thomas and Salter, 2010). In the same study, Thomas and Salter identified membrane phospholipids as the active components of MVs, responsible for upregulation of co-stimulatory receptors and cytokine secretion in non-primed macrophages, through a TLR4-dependent process (Thomas and Salter, 2010).

Consistent with a pro-inflammatory role of MVs shed upon $\mathrm{P}_{2} \mathrm{X}_{7}$ receptor activation our recent data indicate that microgliaderived MVs induce an immuno-stimulatory activity in recipient microglia, which upregulate the co-stimulatory molecule CD86 and express inflammatory genes in a dose dependent manner upon MV exposure (Verderio et al., 2012). The inflammatory reaction occurring in recipient microglia is associated to MV internalization and MVs-mediated transfer of mRNA codifying for IL- $1 \beta$. However, it still unclear whether transfer of genetic information from MVs to target microglia contributes to the inflammatory response induced by $\mathrm{MVs}$ and further studies are required to identify the inflammatory component/s of MVs. Interestingly, we validated in vivo these results by demonstrating that MVs 
of microglial origin are detectable in the cerebrospinal fluids of rodents and that their concentration increases in the course of Experimental Autoimmune Encephalomyelitis (EAE), a model of the prototypic neuroinflammatory disease multiple sclerosis (Verderio et al., 2012). We also found that injection of MVs into the brain of mice with subclinical EAE induces recruitment of inflammatory cells at the site of delivery, while A-SMase knock out mice, genetically impaired in MV production, are largely protected from EAE (Verderio et al., 2012). All together these data indicate that microglia-derived MVs act as amplifying agents of inflammation and identify MVs as a marker and therapeutic target of brain inflammation.

It should be noted, however, that MV shedding can also serve functions other than antigen dissemination and propagation of inflammation. Evidence from Di Virgilio's group and our laboratory (Bianco et al., 2005; Pizzirani et al., 2007), by demonstrating the presence of $\mathrm{P}_{2} \mathrm{X}_{7}$ receptors on isolated vesicles, suggested that MV shedding could represent a defense strategy against apoptotic insults, produced by excessive or repetitive ATP stimulation. Removal of functional $\mathrm{P}_{2} \mathrm{X}_{7}$ receptors from the cell surface could facilitate cell survival and avoid $\mathrm{P}_{2} \mathrm{X}_{7}$-mediated apoptosis (Verderio and Matteoli, 2001).

\section{MICROGLIA-DERIVED MVs ENHANCE EXCITATORY NEUROTRANSMISSION}

Microvesicles however may play a functional role also in different scenarios. In a recent study we explored the potential of MVs produced by microglia to interact with neurons and to modulate neurotransmission (Antonucci et al., 2012). We found that MVs shed from the surface of microglia interact with the plasma membrane of neurons and enhance spontaneous and evoked excitatory transmission. Indeed analysis of miniature excitatory postsynaptic currents (mEPSCs) in neurons acutely exposed to MVs revealed an increase in mEPSC frequency without changes in mEPSC amplitude and paired recording analysis showed an increase the amplitude of EPSCs (Figure 3). MVs mainly act on the presynaptic site of the excitatory synapse, by increasing the ready releasable pool of synaptic vesicles and enhancing release probability at hippocampal synapses. This was indicated by increased sucrose-evoked exocytosis and reduction of paired pulse ratio in synaptically connected neurons. Notably, we found that MVs influence neurotransmission by inducing sphingolipid metabolism in neurons (Figure 4). Direct measurements of sphingolipid metabolism revealed an increase in ceramide and sphingosine production from sphingomyelin in cultured neurons exposed to MVs while pharmacological or genetic inhibition of sphingosine synthesis strongly prevented the stimulatory activity of MVs. Interestingly, the use of empty MVs, depleted of their luminal content, indicated that the presynaptic effect of MVs depends on surface components. Consistent with previous evidence by Thomas and Salter (2010) which identified phospholipids of MV membrane as the active pro-inflammatory agent of the MVs, we found that the lipid fraction of MVs shed from microglia is responsible for the enhancement of excitatory neurotransmission. However, additional studies are required to identify the active lipid/s of MVs and to fully define the receptors involved in MV recognition and coupled to sphingolipid metabolism in neurons.

\section{Is MVs-DEPENDENT STIMULATION OF EXOCYTOSIS GOOD OR BAD FOR NEURONS?}

This question remains still largely unsolved and we can only make some speculative considerations. Previous evidence indicated that
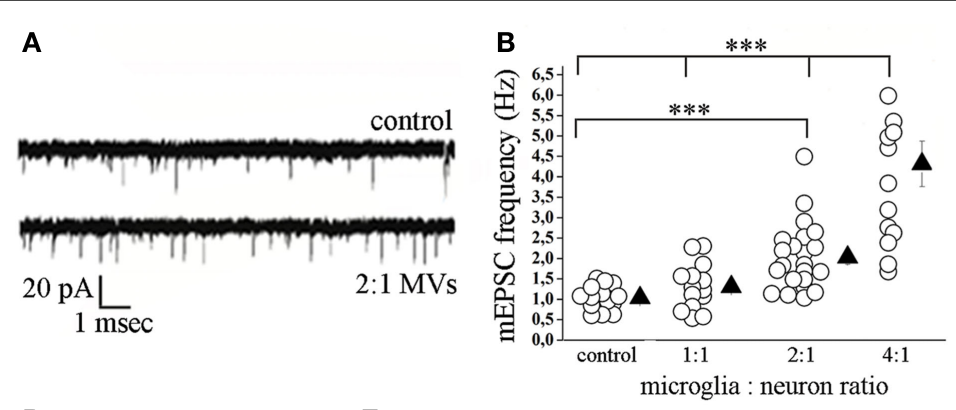

D

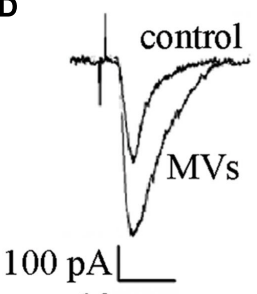

$10 \mathrm{msec}$
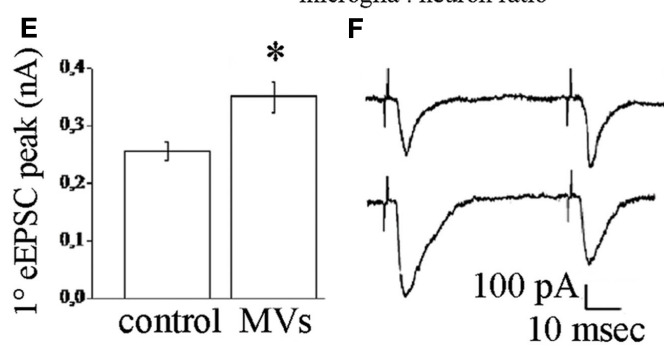

$10 \mathrm{msec}$

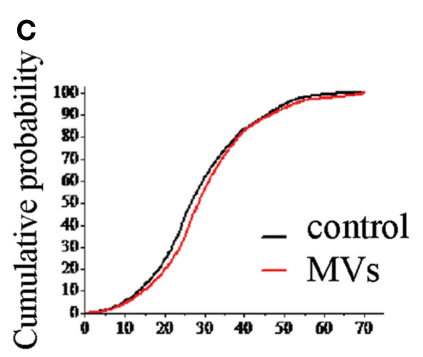

G

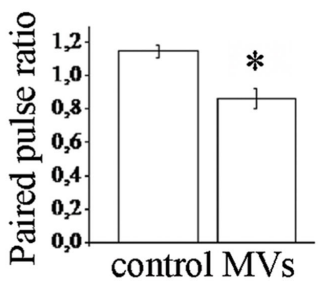

FIGURE 3 | Effect of microglia-derived MVs on neurotransmission in hippocampal cultures. (A) Representative traces of mEPSCs from control neurons and neurons exposed to MVs. (B) Changes of mEPSC frequency evoked by MVs in a microglia to neuron-ratio of 1:1 (MVs concentration $=1.2 \mathrm{mg} / \mathrm{ml}), 2: 1(\mathrm{MVs}$ concentration $=2.38 \mathrm{mg} / \mathrm{ml})$, and $4: 1$ (MVs concentration $=4.76 \mathrm{mg} / \mathrm{ml})$. (C) Cumulative distribution of $\mathrm{mEPSC}$ amplitude from control and MVs-treated neurons. (D-E) Examples of stimulus-evoked EPSCs in control and MVs-treated paired mouse neurons (D) and corresponding mean amplitude (E). (F-G) Representative traces of short-term plasticity in paired mouse neurons (F) (upper trace, control neurons; lower trace, MVs-treated neurons) and quantitative analysis of paired pulse ratio (G). From Antonucci et al. (2012). 


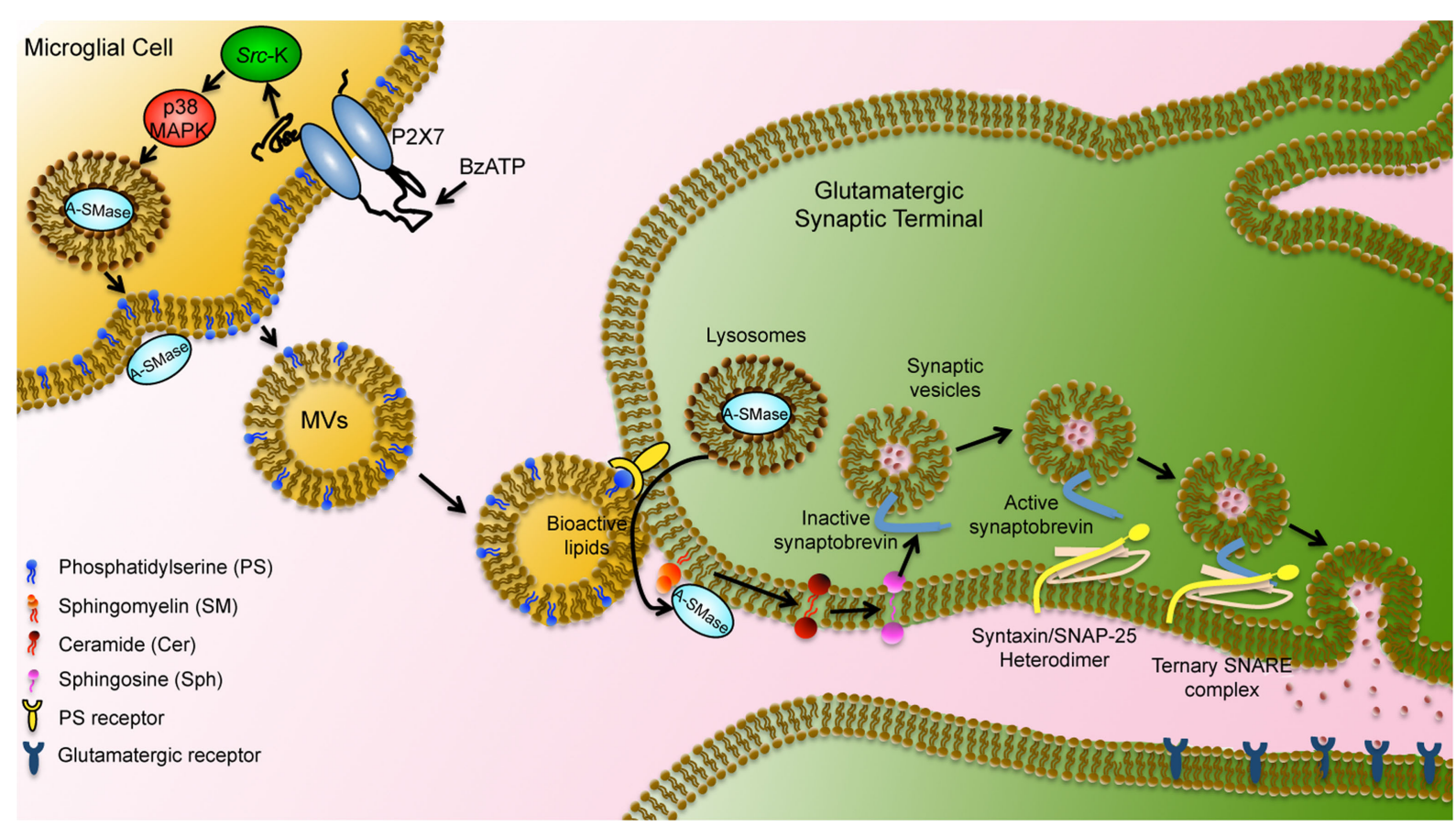

FIGURE 4 | Schematic representation of microglial MV-mediated activity in neurons. MVs shed from the microglial surface have externalized PS and bind via PS receptors to the surface of target neurons. MV lipids stimulate A-SMase activity and promote sphingomyelin metabolism to sphingosine in neurons. Sphingosine, in turn, mediates relief of the cytoplasmic part of synaptobrevin from inhibition by the vesicular membrane and facilitates further interaction with syntaxin/SNAP-25 heterodimer. Ternary SNARE complex formation leads to synaptic vesicle fusion with the plasma membrane modified by Darios et al. (2009).
ATP, the stimulus which triggers MV shedding, is a physiological gliotransmitter but also a typical danger signal, which accumulates in the extracellular microenvironment upon cell damage. The shedding process occurs more efficiently in reactive as compared to resting microglia (Bianco et al., 2009; Qu et al., 2009; Sarkar et al., 2009) and uncontrolled microglial activation is linked to neurotoxicity in a wide range of brain diseases. However there has been considerable debate as to whether the microglia response is good or bad for tissue protection and repair. Accumulating evidence indicates that microglial reaction may indeed support neurons by providing trophic factors, eliminating damaged cells (Olah et al., 2012), controlling neurogenesis (Butovsky et al., 2006) and synaptogenesis (Roumier et al., 2004), and monitoring the functional state of synapses (Wake et al., 2009).

Facilitation of exocytosis induced by microglia-derived MVs may represent a protective response of microglia, aimed at restoring neuronal activity upon functional deficit of synaptic transmission. Neurons constitutively release a number of "Off" signals capable of inhibiting microglia activation (Neumann et al., 1998; Mott et al., 2004; Biber et al., 2007). Thus reduction in secretion of "Off" signals at damaged synapses may favor the acquisition of reactive phenotype in surrounding microglia, and facilitate MV shedding to restore exocytosis. Alternatively, and more probably, MVs may impact neurotransmission in case of microglia overshooting. By causing overproduction of sphingolipids, MVs shed from reactive microglia may contribute to the excessive potentiation of excitatory transmission, which indeed occurs in neuroinflammatory and degenerative diseases (DeFelice et al., 2007; Busche et al., 2008; Centonze et al., 2009). Characterization of $\mathrm{MV}$ content in relation to the activation state of donor microglia may help deciphering the complex biological activity MVs may exert toward neurons either upon acute or chronic delivery in both physiological and pathological conditions.

\section{CONCLUSION AND FUTURE PERSPECTIVE}

Similar to membrane vesicles released by most cells, MVs shed from the surface of microglia contain various bioactive molecules which modulate neuron functionality and also influence the activity of surrounding non-neuronal cells. MVs contain a pro-inflammatory signals, i.e., IL-1 $\beta$ together with proteases and MHCII protein, act as amplifiers of inflammatory signals between glial cells and stimulate excitatory neurotransmission. This evidence suggests that MVs may play a pathogenic role not only in neuroinflammatory diseases, such as multiple sclerosis, but also in degenerative brain diseases, like Alzheimer's disease, where microglia is activated and IL-1 $\beta$ is implicated (Giulian et al., 1996; Lue et al., 2005). Hence, a better understanding of the molecular mechanisms involved in MV shedding and in the transfer of the inflammatory signals may help identifying a strategy to inhibit MV activity, which may be of therapeutic relevance for the treatment of inflammatory brain diseases. Few, important pieces of information are already available: we know the stimulus (ATP), the receptor $\left(\mathrm{P} 2 \mathrm{X}_{7}\right.$ receptor), and the key enzyme (acid sphingomyelinase) 
involved in regulated shedding of MVs from microglia. We can inhibit production of MVs with pharmacological and genetic tools and we can envisage a sorting mechanism for constituents of MVs which interact directly with the $\mathrm{P}_{2} \mathrm{X}_{7}$ receptor or indirectly through its signaling components. However, the molecular composition of microglia-derived vesicles remains largely to be defined and little information are available about possible changes of MV cargo in relation to the activation state of donor microglia. A detailed characterization of proteins, lipids, and genetic components sorted inside MVs may greatly help deciphering the message stored inside MVs and sent by resting or reactive microglia toward surrounding cells, including non-neuronal cells such as astrocytes, oligodendrocytes, and other microglia. Also, the elucidation of intercellular trafficking of MVs and identification of ligandreceptor recognition events which mediate the specific interactions between MVs and target cells might facilitate the comprehension of the biological activity exerted by microglia-derived MVs toward distinct brain cells.

\section{REFERENCES}

Alais, S., Simoes, S., Baas, D., Lehmann, S., Raposo, G., Darlix, J. L., and Leblanc, P. (2008). Mouse neuroblastoma cells release prion infectivity associated with exosomal vesicles. Biol. Cell 100, 603-615.

Al-Nedawi, K., Meehan, B., and Rak, J. (2009). Microvesicles: messengers and mediators of tumor progression. Cell Cycle 8, 2014-2018.

Andrei, C., Dazzi, C., Lotti, L., Torrisi, M. R., Chimini, G., and Rubartelli, A. (1999). The secretory route of the leaderless protein interleukin lbeta involves exocytosis of endolysosome-related vesicles. $\mathrm{Mol}$. Biol. Cell 10, 1463-1475.

Antonucci, F., Turola, E., Riganti, L., Caleo, M., Gabrielli, M., Perrotta, C., Novellino, L., Clementi, E., Giussani, P., Viani, P., Matteoli, M., and Verderio, C. (2012). Microvesicles released from microglia stimulate synaptic activity via enhanced sphingolipid metabolism. EMBO J. 31, 1231-1240.

Babst, M. (2005). A protein's final ESCRT. Traffic 6, 2-9.

Bakhti, M., Winter, C., and Simons, M. (2011). Inhibition of myelin membrane sheath formation by oligodendrocyte-derived exosomelike vesicles. J. Biol. Chem. 286, 787-796.

Balcaitis, S., Weinstein, J. R., Li, S., Chamberlain, J. S., and Moller, T. (2005). Lentiviral transduction of microglial cells. Glia 50, 48-55.

Bernimoulin, M., Waters, E. K., Foy, M., Steele, B. M., Sullivan, M., Falet, H., Walsh, M. T., Barteneva, N., Geng, J. G., Hartwig, J. H., Maguire, P. B., and Wagner, D. D. (2009).
Differential stimulation of monocytic cells results in distinct populations of microparticles. J. Thromb. Haemost. 7, 1019-1028.

Bianco, F., Perrotta, C., Novellino, L., Francolini, M., Riganti, L., Menna, E., Saglietti, L., Schuchman, E. H., Furlan, R., Clementi, E., Matteoli, M., and Verderio, C. (2009). Acid sphingomyelinase activity triggers microparticle release from glial cells. EMBO J. 28, 1043-1054.

Bianco, F., Pravettoni, E., Colombo, A., Schenk, U., Moller, T., Matteoli, M., and Verderio, C. (2005). Astrocyte-derived ATP induces vesicle shedding and IL-1 beta release from microglia. J. Immunol. 174, 7268-7277.

Biber, K., Neumann, H., Inoue, K. and Boddeke, H. W. (2007). Neuronal "On" and "Off"' signals control microglia. Trends Neurosci. 30, 596-602.

Budagian, V., Bulanova, E., Brovko, L., Orinska, Z., Fayad, R., Paus, R., and Bulfone-Paus, S. (2003). Signaling through $\mathrm{P} 2 \mathrm{X} 7$ receptor in human $\mathrm{T}$ cells involves p56lck, MAP kinases, and transcription factors AP-1 and NF-kappa B. J. Biol. Chem. 278, 1549-1560.

Busche, M. A., Eichhoff, G., Adelsberger, H., Abramowski, D., Wiederhold, K. H., Haass, C., Staufenbiel, M., Konnerth, A., and Garaschuk, O. (2008). Clusters of hyperactive neurons near amyloid plaques in a mouse model of Alzheimer's disease. Science 321, 1686-1689.

Butovsky, O., Ziv, Y., Schwartz, A., Landa, G., Talpalar, A. E., Pluchino, S., Martino, G., and Schwartz, M. (2006). Microglia activated by IL-4 or IFN-gamma differentially induce

In vivo studies will greatly benefit from the creation of a mouse model, in which MV shedding can be inducible impaired, such as conditional A-SMase knock out mice. A further improvement would derive from selective and inducible inactivation of A-SMase in microglia as this would avoid the complex phenotype of currently available models, in which constitutive inactivation of the gene in all cells produces a phenotype similar to Niemann-Pick type A human disorder (Horinouchi et al., 1995; Otterbach and Stoffel, 1995). Furthermore the development of highly specific A-SMase inhibitors could reveal a therapeutic potential of MV shedding inhibitors in brain inflammation.

\section{ACKNOWLEDGMENTS}

We thank Paola Viani and Martina Gabrielli (University of Milan) for helpful discussion. This study was supported in part by FISM 2010/R/39, Italian Ministry 2008XFMEA3, RS 2008 B45E11000030008 to Claudia Verderio, and CARIPLO 20083184 to Michela Matteoli.

neurogenesis and oligodendrogenesis from adult stem/progenitor cells. Mol. Cell. Neurosci. 31, 149-160.

Centonze, D., Muzio, L., Rossi, S., Cavasinni, F., De Chiara, V. Bergami, A., Musella, A., D’Amelio, M., Cavallucci, V., Martorana, A. Bergamaschi, A., Cencioni, M. T. Diamantini, A., Butti, E., Comi, G., Bernardi, G., Cecconi, F., Battistini, L., Furlan, R., and Martino, G. (2009). Inflammation triggers synaptic alteration and degeneration in experimental autoimmune encephalomyelitis. J. Neurosci. 29, 3442-3452.

Ceruti, S., Colombo, L., Magni, G., Vigano, F., Boccazzi, M., Deli, M. A., Sperlagh, B., Abbracchio, M. P., and Kittel, A. (2011). Oxygen-glucose deprivation increases the enzymatic activity and the microvesiclemediated release of ectonucleotidases in the cells composing the blood-brain barrier. Neurochem. Int 59, 259-271.

Chahed, S., Leroyer, A. S., Benzerroug, M., Gaucher, D., Georgescu, A., Picaud, S., Silvestre, J. S., Gaudric, A., Tedgui, A., Massin, P., and Boulanger, C. M. (2010). Increased vitreous shedding of microparticles in proliferative diabetic retinopathy stimulates endothelial proliferation. Diabetes 59, 694-701.

Chang, C. P., Zhao, J., Wiedmer, T., and Sims, P. J. (1993). Contribution of platelet microparticle formation and granule secretion to the transmembrane migration of phosphatidylserine. J. Biol. Chem. 268, 7171-7178.

Chen, C., Skog, J., Hsu, C. H., Lessard, R. T., Balaj, L., Wurdinger, T., Carter, B. S., Breakefield, X. O., Toner, M. and Irimia, D. (2010). Microfluidic isolation and transcriptome analysis of serum microvesicles. Lab Chip 10, 505-511.

Cockcroft, S., and Gomperts, B. D. (1979). ATP induces nucleotide permeability in rat mast cells. Nature 279, 541-542.

Cocucci, E., and Meldolesi, J. (2011). Ectosomes. Curr. Biol. 21, R940R941.

Cocucci, E., Racchetti, G., and Meldolesi, J. (2009). Shedding microvesicles: artefacts no more. Trends Cell Biol. 19, 43-51.

Darios, F., Wasser, C., Shakirzyanova, A., Giniatullin, A., Goodman, K., Munoz-Bravo, J. L., Raingo, J., Jorgacevski, J., Kreft, M., Zorec, R., Rosa, J. M., Gandia, L., Gutiérrez, L. M., Binz, T., Giniatullin, R., Kavalali, E.T., and Davletov, B. (2009). Sphingosine facilitates SNARE complex assembly and activates synaptic vesicle exocytosis. Neuron 62, 683-694.

David, S., and Kroner, A. (2011). Repertoire of microglial and macrophage responses after spinal cord injury. Nat. Rev. Neurosci. 12, 388-399.

Del Conde, I., Shrimpton, C. N., Thiagarajan, P., and Lopez, J. A. (2005). Tissue-factor-bearing microvesicles arise from lipid rafts and fuse with activated platelets to initiate coagulation. Blood 106, 1604-1611.

De Felice, F. G., Velasco, P. T., Lambert, M. P., Viola, K., Fernandez, S. J., Ferreira, S. T., and Klein, W. L. (2007). Abeta oligomers induce neuronal oxidative stress through an N-methyl-D-aspartate receptor-dependent mechanism that is blocked by the Alzheimer drug memantine. J. Biol. Chem. 282, 11590-11601. 
Denlinger, L. C., Fisette, P. L., Sommer, J. A., Watters, J. J., Prabhu, U., Dubyak, G. R., Proctor, R. A., and Bertics, P. J. (2001). Cutting edge: the nucleotide receptor P2X7 contains multiple protein- and lipid-interaction motifs including a potential binding site for bacterial lipopolysaccharide. J. Immunol. 167, 1871-1876.

Doeuvre, L., Plawinski, L., Toti, F., and Angles-Cano, E. (2009). Cellderived microparticles: a new challenge in neuroscience. J. Neurochem. 110, 457-468.

Dragovic, R. A., Gardiner, C., Brooks, A. S., Tannetta, D. S., Ferguson, D. J., Hole, P., Carr, B., Redman, C. W., Harris, A. L., Dobson, P. J., Harrison, P., and Sargent, I. L. (2011). Sizing and phenotyping of cellular vesicles using nanoparticle tracking analysis. Nanomedicine 7, 780-788

Duan, S., and Neary, J. T. (2006). P2X(7) receptors: properties and relevance to CNS function. Glia 54, 738-746.

Dukers, D. F., Meij, P., Vervoort, M. B., Vos, W., Scheper, R. J., Meijer, C. J., Bloemena, E., and Middeldorp, J. M. (2000). Direct immunosuppressive effects of EBV-encoded latent membrane protein 1. J. Immunol. 165, 663-670.

Fang, Y., Wu, N., Gan, X., Yan, W., Morrell, J. C., and Gould, S. J. (2007). Higher-order oligomerization targets plasma membrane proteins and HIV gag to exosomes. PLoS Biol. 5, e158. doi:10.1371/journal.pbio.0050158

Faure, J., Lachenal, G., Court, M., Hirrlinger, J., Chatellard-Causse, C., Blot, B., Grange, J., Schoehn, G., Goldberg, Y., Boyer, V., Kirchhoff, F., Raposo, G., Garin, J., and Sadoul, R. (2006). Exosomes are released by cultured cortical neurones. Mol. Cell. Neurosci. 31, 642-648.

Ferrari, D., Chiozzi, P., Falzoni, S., Dal Susino, M., Collo, G., Buell, G., and Di Virgilio, F. (1997). ATPmediated cytotoxicity in microglial cells. Neuropharmacology 36, 1295-1301.

Ferrari, D., Pizzirani, C., Adinolfi, E., Lemoli, R. M., Curti, A., Idzko, M., Panther, E., and Di Virgilio, F. (2006). The P2X7 receptor: a key player in IL-1 processing and release. J. Immunol. 176, 3877-3883.

Fevrier, B., Vilette, D., Archer, F., Loew, D., Faigle, W., Vidal, M., Laude, H., and Raposo, G. (2004). Cells release prions in association with exosomes. Proc. Natl. Acad. Sci. U.S.A. 101, 9683-9688.
Fitzner, D., Schnaars, M., Van Rossum, D., Krishnamoorthy, G., Dibaj, P., Bakhti, M., Regen, T., Hanisch, U. K., and Simons, M. (2011). Selective transfer of exosomes from oligodendrocytes to microglia by macropinocytosis. J. Cell Sci. 124, 447-458.

Gan, X., and Gould, S. J. (2011). Identification of an inhibitory budding signal that blocks the release of HIV particles and exosome/microvesicle proteins. Mol. Biol. Cell 22, 817-830.

Ghidoni, R., Paterlini, A., Albertini, V., Glionna, M., Monti, E., Schiaffonati, L., Benussi, L., Levy, E., and Binetti, G. (2011). Cystatin C is released in association with exosomes: a new tool of neuronal communication which is unbalanced in Alzheimer's disease. Neurobiol. Aging 32, 1435-1442.

Giulian, D., Haverkamp, L. J., Yu, J. H., Karshin, W., Tom, D., Li, J., Kirkpatrick, J., Kuo, L. M., and Roher, A. E. (1996). Specific domains of beta-amyloid from Alzheimer plaque elicit neuron killing in human microglia. J. Neurosci. 16, 6021-6037.

Gould, S. J., Booth, A. M., and Hildreth, J. E. (2003). The Trojan exosome hypothesis. Proc. Natl. Acad. Sci. U.S.A. 100, 10592-10597.

Grassme, H., Jekle, A., Riehle, A., Schwarz, H., Berger, J., Sandhoff, K., Kolesnick, R., and Gulbins, E. (2001). CD95 signaling via ceramide-rich membrane rafts. J. Biol. Chem. 276, 20589-20596.

Guescini, M., Genedani, S., Stocchi, V., and Agnati, L. F. (2010). Astrocytes and glioblastoma cells release exosomes carrying mtDNA. J. Neural Transm. 117, 1-4.

Gulbins, E., and Kolesnick, R. (2003). Raft ceramide in molecular medicine. Oncogene 22, 7070-7077.

Hanson, P. I., Shim, S., and Merrill, S. A. (2009). Cell biology of the ESCRT machinery. Curr. Opin. Cell Biol. 21, 568-574.

Hide, I., Tanaka, M., Inoue, A., Nakajima, K., Kohsaka, S., Inoue, K., and Nakata, Y. (2000). Extracellular ATP triggers tumor necrosis factor-alpha release from rat microglia. J. Neurochem. 75, 965-972.

Hogquist, K. A., Nett, M. A., Unanue, E. R., and Chaplin, D. D. (1991). Interleukin 1 is processed and released during apoptosis. Proc. Natl. Acad. Sci. U.S.A. 88, 8485-8489.
Horinouchi, K., Erlich, S., Perl, D. P., Ferlinz, K., Bisgaier, C. L., Sandhoff, K., Desnick, R. J., Stewart, C. L., and Schuchman, E. H. (1995). Acid sphingomyelinase deficient mice: a model of types A and B Niemann-Pick disease. Nat. Genet. 10, 288-293.

Horstman, L. L., Jy, W., Minagar, A., Bidot, C. J., Jimenez, J. J., Alexander, J. S., and Ahn, Y. S. (2007). Cell-derived microparticles and exosomes in neuroinflammatory disorders. Int. Rev. Neurobiol. 79, 227-268.

Hugel, B., Martinez, M. C., Kunzelmann, C., and Freyssinet, J. M. (2005). Membrane microparticles: two sides of the coin. Physiology 20, 22-27.

Keller, S., Konig, A. K., Marme, F., Runz, S., Wolterink, S., Koensgen, D., Mustea, A., Sehouli, J., and Altevogt, P. (2009). Systemic presence and tumor-growth promoting effect of ovarian carcinoma released exosomes. Cancer Lett. 278, 73-81.

Kolotuev, I., Apaydin, A., and Labouesse, M. (2009). Secretion of Hedgehogrelated peptides and WNT during Caenorhabditis elegans development. Traffic 10, 803-810.

Korkut, C., Ataman, B., Ramachandran, P., Ashley, J., Barria, R., Gherbesi, N., and Budnik, V. (2009). Transsynaptic transmission of vesicular Wnt signals through Evi/Wntless. Cell 139, 393-404.

Kramer-Albers, E. M., Bretz, N., Tenzer, S., Winterstein, C., Mobius, W. Berger, H., Nave, K. A., Schild, H., and Trotter, J. (2007). Oligodendrocytes secrete exosomes containing major myelin and stress-protective proteins: trophic support for axons? Proteomics Clin. Appl. 1, 1446-1461.

Lachenal, G., Pernet-Gallay, K., Chivet, M., Hemming, F. J., Belly, A., Bodon, G., Blot, B., Haase, G., Goldberg, Y., and Sadoul, R. (2011). Release of exosomes from differentiated neurons and its regulation by synaptic glutamatergic activity. Mol. Cell. Neurosci. 46, 409-418.

Leblanc, P., Alais, S., Porto-Carreiro, I., Lehmann, S., Grassi, J., Raposo, G. and Darlix, J. L. (2006). Retrovirus infection strongly enhances scrapie infectivity release in cell culture. EMBO J. 25, 2674-2685.

Liegeois, S., Benedetto, A., Garnier, J. M., Schwab, Y., and Labouesse, M. (2006). The V0-ATPase mediates apical secretion of exosomes containing Hedgehog-related proteins in Caenorhabditis elegans. J. Cell Biol. 173, 949-961.
Logozzi, M., De Milito, A., Lugini, L., Borghi, M., Calabro, L., Spada, M., Perdicchio, M., Marino, M. L., Federici, C., Iessi, E., Brambilla, D., Venturi, G., Lozupone, F., Santinami, M., Huber, V., Maio, M., Rivoltini, L., and Fais, S. (2009). High levels of exosomes expressing CD63 and caveolin-1 in plasma of melanoma patients. PLOS ONE 4, e5219. doi:10.1371/journal.pone.0005219

Lue, L. F., Yan, S. D., Stern, D. M., and Walker, D. G. (2005). Preventing activation of receptor for advanced glycation endproducts in Alzheimer's disease. Curr. Drug Targets CNS Neurol. Disord. 4, 249-266.

MacKenzie, A., Wilson, H. L., KissToth, E., Dower, S. K., North, R. A., and Surprenant, A. (2001). Rapid secretion of interleukin-1beta by microvesicle shedding. Immunity 15, 825-835.

Mantovani, A., and Locati, M. (2009). Orchestration of macrophage polarization. Blood 114, 3135-3136.

Marchesini, N., and Hannun, Y. A. (2004). Acid and neutral sphingomyelinases: roles and mechanisms of regulation. Biochem. Cell Biol. 82, 27-44.

Matsuo, H., Chevallier, J., Mayran, N., Le Blanc, I., Ferguson, C., Faure, J., Blanc, N. S., Matile, S., Dubochet, J., Sadoul, R., Parton, R. G., Vilbois, F., and Gruenberg, J. (2004). Role of LBPA and Alix in multivesicular liposome formation and endosome organization. Science 303, 531-534.

Morelli, A., Chiozzi, P., Chiesa, A., Ferrari, D., Sanz, J. M., Falzoni, S., Pinton, P., Rizzuto, R., Olson, M. F., and Di Virgilio, F. (2003). Extracellular ATP causes ROCK I-dependent bleb formation in P2X7-transfected HEK293 cells. Mol. Biol. Cell 14, 2655-2664.

Mott, R. T., Ait-Ghezala, G., Town, T., Mori, T., Vendrame, M., Zeng, J., Ehrhart, J., Mullan, M., and Tan, J. (2004). Neuronal expression of CD22: novel mechanism for inhibiting microglial proinflammatory cytokine production. Glia 46 , 369-379.

Muralidharan-Chari, V., Clancy, J., Plou, C., Romao, M., Chavrier, P., Raposo, G., and D'Souza-Schorey, C. (2009). ARF6-regulated shedding of tumor cell-derived plasma membrane microvesicles. Curr. Biol. 19, 1875-1885.

Nazarenko, I., Rana, S., Baumann, A., Mcalear, J., Hellwig, A., Trendelenburg, M., Lochnit, G., Preissner, K. T., and Zoller, M. (2010). Cell surface tetraspanin Tspan 8 
contributes to molecular pathways of exosome-induced endothelial cell activation. Cancer Res. 70, 1668-1678.

Neufeld, E. B., Cooney, A. M., Pitha, J., Dawidowicz, E. A., Dwyer, N. K., Pentchev, P. G., and BlanchetteMackie, E. J. (1996). Intracellular trafficking of cholesterol monitored with a cyclodextrin. J. Biol. Chem. 271, 21604-21613.

Neumann, H., Misgeld, T., Matsumuro, K., and Wekerle, H. (1998). Neurotrophins inhibit major histocompatibility class II inducibility of microglia: involvement of the p75 neurotrophin receptor. Proc. Natl. Acad. Sci. U.S.A. 95, 5779-5784.

Olah, M., Amor, S., Brouwer, N., Vinet, J., Eggen, B., Biber, K., and Boddeke, H. W. (2012). Identification of a microglia phenotype supportive of remyelination. Glia 60 , 306-321.

Otterbach, B., and Stoffel, W. (1995). Acid sphingomyelinase-deficient mice mimic the neurovisceral form of human lysosomal storage disease (Niemann-Pick disease). Cell 81, 1053-1061.

Pap, E., Pallinger, E., Pasztoi, M., and Falus, A. (2009). Highlights of a new type of intercellular communication: microvesicle-based information transfer. Inflamm. Res. 58, 1-8.

Perrotta, C., Bizzozero, L., Cazzato, D., Morlacchi, S., Assi, E., Simbari, F., Zhang, Y., Gulbins, E., Bassi, M. T., Rosa, P., and Clementi, E. (2010). Syntaxin 4 is required for acid sphingomyelinase activity and apoptotic function. J. Biol. Chem. 285, 40240-40251.

Piccin, A., Murphy, W. G., and Smith, O. P. (2007). Circulating microparticles: pathophysiology and clinical implications. Blood Rev. 21, 157-171.

Pizzirani, C., Ferrari, D., Chiozzi, P., Adinolfi, E., Sandona, D., Savaglio, E., and Di Virgilio, F. (2007). Stimulation of $\mathrm{P} 2$ receptors causes release of IL-1beta-loaded microvesicles from human dendritic cells. Blood 109, 3856-3864.

Potolicchio, I., Carven, G. J., Xu, X., Stipp, C., Riese, R. J., Stern, L. J., and Santambrogio, L. (2005). Proteomic analysis of microglia-derived exosomes: metabolic role of the aminopeptidase CD13 in neuropeptide catabolism. J. Immunol. 175, 2237-2243.

Proia, P., Schiera, G., Mineo, M., Ingrassia, A. M., Santoro, G., Savettieri, G., and Di Liegro, I. (2008).
Astrocytes shed extracellular vesicles that contain fibroblast growth factor-2 and vascular endothelial growth factor. Int. J. Mol. Med. 21, 63-67.

Qu, Y., Franchi, L., Nunez, G., and Dubyak, G. R. (2007). Nonclassical IL-1 beta secretion stimulated by $\mathrm{P} 2 \mathrm{X} 7$ receptors is dependent on inflammasome activation and correlated with exosome release in murine macrophages. J. Immunol. 179, 1913-1925.

Qu, Y., Ramachandra, L., Mohr, S. Franchi, L., Harding, C. V., Nunez, G., and Dubyak, G. R. (2009). $\mathrm{P} 2 \mathrm{X} 7$ receptor-stimulated secretion of MHC class II-containing exosomes requires the ASC/NLRP3 inflammasome but is independent of caspase-1. J. Immunol. 182, 5052-5062.

Ransohoff, R. M., and Cardona, A. E. (2010). The myeloid cells of the central nervous system parenchyma. Nature 468, 253-262.

Roumier, A., Bechade, C., Poncer, J. C., Smalla, K. H., Tomasello, E., Vivier, E., Gundelfinger, E. D., Triller, A., and Bessis, A. (2004). Impaired synaptic function in the microglial KARAP/DAP12deficient mouse. J. Neurosci. 24, 11421-11428.

Sadallah, S., Eken, C., and Schifferli, J. A. (2011). Ectosomes as modulators of inflammation and immunity. Clin. Exp. Immunol. 163, 26-32.

Saijo, K., and Glass, C. K. (2011). Microglial cell origin and phenotypes in health and disease. Nat. Rev. Immunol. 11, 775-787.

Sarkar, A., Mitra, S., Mehta, S., Raices, R., and Wewers, M. D. (2009). Monocyte derived microvesicles deliver a cell death message via encapsulated caspase-1. PLoS ONE 4, e7140. doi:10.1371/journal.pone.0007140

Sbai, O., Ould-Yahoui, A., Ferhat, L., Gueye, Y., Bernard, A., Charrat, E., Mehanna, A., Risso, J. J., Chauvin, J. P., Fenouillet, E., Rivera, S., and Khrestchatisky, M. (2010). Differential vesicular distribution and trafficking of MMP-2, MMP-9, and their inhibitors in astrocytes. Glia 58, 344-366.

Schiera, G., Proia, P., Alberti, C., Mineo, M., Savettieri, G., and Di Liegro, I. (2007). Neurons produce FGF2 and VEGF and secrete them at least in part by shedding extracellular vesicles. J. Cell. Mol. Med. 11, 1384-1394.

Scolding, N. J., Morgan, B. P., Houston, W. A., Linington, C., Campbell, A. K., and Compston, D. A. (1989).
Vesicular removal by oligodendrocytes of membrane attack complexes formed by activated complement. Nature 339, 620-622.

Simons, K., and Ikonen, E. (1997). Functional rafts in cell membranes. Nature 387, 569-572.

Simons, M., and Raposo, G. (2009). Exosomes - vesicular carriers for intercellular communication. Curr. Opin. Cell Biol. 21, 575-581.

Sims, P. J., and Wiedmer, T. (2001). Unraveling the mysteries of phospholipid scrambling. Thromb. Haemost. 86, 266-275.

Slotte, J. P., Hedstrom, G., Rannstrom, S., and Ekman, S. (1989). Effects of sphingomyelin degradation on cell cholesterol oxidizability and steadystate distribution between the cell surface and the cell interior. Biochim. Biophys. Acta 985, 90-96.

Steinberg, T. H., Newman, A. S., Swanson, J. A., and Silverstein, S. C. (1987). ATP4-permeabilizes the plasma membrane of mouse macrophages to fluorescent dyes. J. Biol. Chem. 262, 8884-8888.

Strauss, K., Goebel, C., Runz, H. Mobius, W., Weiss, S., Feussner, I., Simons, M., and Schneider, A. (2010). Exosome secretion ameliorates lysosomal storage of cholesterol in Niemann-Pick type C disease. J. Biol. Chem. 285, 26279-26288.

Subra, C., Laulagnier, K., Perret, B. and Record, M. (2007). Exosome lipidomics unravels lipid sorting at the level of multivesicular bodies. Biochimie 89, 205-212.

Tamboli, I. Y., Barth, E., Christian, L., Siepmann, M., Kumar, S. Singh, S., Tolksdorf, K., Heneka, M. T., Lutjohann, D., Wunderlich, P., and Walter, J. (2010) Statins promote the degradation of extracellular amyloid \{beta\}peptide by microglia via stimulation of exosome-associated insulindegrading enzyme (IDE) secretion. J. Biol. Chem. 285, 37405-37414

Taylor, A. R., Robinson, M. B., Gifondorwa, D. J., Tytell, M., and Milligan, C. E. (2007). Regulation of heat shock protein 70 release in astrocytes: role of signaling kinases. Dev. Neurobiol. 67, 1815-1829.

Tepper, A. D., Ruurs, P., Wiedmer, T., Sims, P. J., Borst, J., and Van Blitterswijk, W. J. (2000). Sphingomyelin hydrolysis to ceramide during the execution phase of apoptosis results from phospholipid scrambling and alters cellsurface morphology. J. Cell Biol. 150, 155-164.
Thery, C., Ostrowski, M., and Segura, E. (2009). Membrane vesicles as conveyors of immune responses. Nat. Rev. Immunol. 9, 581-593.

Thomas, L. M., and Salter, R. D. (2010). Activation of macrophages by P2X7induced microvesicles from myeloid cells is mediated by phospholipids and is partially dependent on TLR4. J. Immunol. 185, 3740-3749.

Trajkovic, K., Hsu, C., Chiantia, S., Rajendran, L., Wenzel, D., Wieland, F., Schwille, P., Brugger, B., and Simons, M. (2008). Ceramide triggers budding of exosome vesicles into multivesicular endosomes. Science 319, 1244-1247.

Van Blitterswijk, W. J., De Veer, G., Krol, J. H., and Emmelot, P. (1982). Comparative lipid analysis of purified plasma membranes and shed extracellular membrane vesicles from normal murine thymocytes and leukemic GRSL cells. Biochim. Biophys. Acta 688, 495-504.

Vella, L. J., Greenwood, D. L., Cappai, R., Scheerlinck, J. P., and Hill, A. F. (2008). Enrichment of prion protein in exosomes derived from ovine cerebral spinal fluid. Vet. Immunol. Immunopathol. 124, 385-393.

Verderio, C., and Matteoli, M. (2001). ATP mediates calcium signaling between astrocytes and microglial cells: modulation by IFN-gamma. J. Immunol. 166, 6383-6391.

Verderio, C., Muzio, L., Turola, E., Bergami, A., Novellino, L., Ruffini, F., Riganti, L., Corradini, I., Francolini, M., Garzetti, L., Maiorino, C., Servida, F., Vercelli, A., Rocca, M., Dalla Libera, D., Martinelli, V., Comi, G., Martino, G., Matteoli, M., and Furlan, R. (2012). Myeloid microvesicles are a marker and a therapeutic target for neuroinflammation. Ann. Neurol. doi: 10.1002/ana.23627

Verhoef, P. A., Estacion, M., Schilling, W., and Dubyak, G. R. (2003) P2 ( 7 receptor-dependent blebbing and the activation of Rhoeffector kinases, caspases, and IL1 beta release. J. Immunol. 170, 5728-5738.

Visentin, S., and Levi, G. (1997). Protein kinase $\mathrm{C}$ involvement in the resting and interferon-gammainduced $\mathrm{K}+$ channel profile of microglial cells. J. Neurosci. Res. 47, 233-241.

Wake, H., Moorhouse, A. J., Jinno, S., Kohsaka, S., and Nabekura, J. (2009). Resting microglia directly monitor the functional state of synapses in vivo and determine the fate of 
ischemic terminals. J. Neurosci. 29, 3974-3980.

Wang, S., Cesca, F., Loers, G., Schweizer, M., Buck, F., Benfenati, F., Schachner, M., and Kleene, R. (2011). Synapsin I is an oligomannose-carrying glycoprotein, acts as an oligomannosebinding lectin, and promotes neurite outgrowth and neuronal survival when released via glia-derived exosomes. J. Neurosci. 31, 7275-7290.

Wollert, T., and Hurley, J. H. (2010). Molecular mechanism of multivesicular body biogenesis by ESCRT complexes. Nature 464, 864-869.

Wollert, T., Yang, D., Ren, X., Lee, H. H., Im, Y. J., and Hurley, J. H. (2009).
The ESCRT machinery at a glance. J. Cell Sci. 122, 2163-2166.

Yu, X., Harris, S. L., and Levine, A. J. (2006). The regulation of exosome secretion: a novel function of the p53 protein. Cancer Res. 66, 4795-4801.

Yu, X., Riley, T., and Levine, A. J. (2009). The regulation of the endosomal compartment by p53 the tumor suppressor gene. FEBS J. 276, 2201-2212.

Yuyama, K., Sun, H., Mitsutake, S., and Igarashi, Y. (2012). Sphingolipidmodulated exosome secretion promotes the clearance of amyloidbeta by microglia. J. Biol. Chem. 287, 10977-10989.
Zwaal, R. F., and Schroit, A. J. (1997). Pathophysiologic implications of membrane phospholipid asymmetry in blood cells. Blood 89, 1121-1132.

Conflict of Interest Statement: The authors declare that the research was conducted in the absence of any commercial or financial relationships that could be construed as a potential conflict of interest.

Received: 15 February 2012; paper pending published: 06 March 2012; accepted: 02 May 2012; published online: 22 May 2012.
Citation: Turola E, Furlan R, Bianco F, Matteoli $M$ and Verderio C (2012) Microglial microvesicle secretion and intercellular signaling. Front. Physio. 3:149. doi: 10.3389/fphys.2012.00149

This article was submitted to Frontiers in Membrane Physiology and Biophysics, a specialty of Frontiers in Physiology. Copyright (C) 2012 Turola, Furlan, Bianco, Matteoli and Verderio. This is an open-access article distributed under the terms of the Creative Commons Attribution Non Commercial License, which permits non-commercial use, distribution, and reproduction in other forums, provided the original authors and source are credited. 